\title{
Antioxidant Activity of Phenolic and Alkaloid Fractions Accumulated in Artemisia Judaica and Artemisia Herba Alba
}

\author{
Eman Ramadan Elsharkawy ${ }^{1,2 *}$ and Mohamed H. Shiboob ${ }^{3}$ \\ 'Department of Eco- physiology, Plant Ecology and Range Management, Desert Research Center, Cairo, \\ Egypt; elsharqawyeman2017@gmail.com \\ ${ }^{2}$ Chemistry Department, Faculty of Science, Northern Borders University, Saudi Arabia \\ ${ }^{3}$ Department of Environmental Sciences, Faculty of Meteorology, Environment and Arid Land Agriculture, \\ King Abdulaziz University, Jeddah, Kingdom of Saudi Arabia
}

\begin{abstract}
Genus Artemisia are desert plants spread in the Egypt and Saudi Arabia. The methanol extract of the aerial parts of Artemisia herba alba and Artemisia judaica grown in the arid zones in the Northern regions of Saudi Arabia and North Sinai, in Egypt were subjected to the primary phytochemical analysis which, showed the presence of phenolic compounds, flavonoids, tannins and sterols. The GC-MS analysis of the methanolic extract exhibited numerous compounds, 11 compounds were identified as phenolic compounds, ferulic acid, ursodeoxycholic acid and derivatives of cinnamic acid (ethyl cinnamate). The highest phenolics content in A.herba alba grown in Saudi Arabia was observed for methyl cinnamate, $(8.2 \%)$ and the lowest methyl ferulate $(0.02 \%)$ for $A$. judica grown in Egypt. The quantization analysis of GC-MS revealed high amount of phenolic acid in the plant grow in Saudi Arabia than the plant collected from Egypt. The radical scavenging activities of two plant were studied by 1,1-diphenyl-2-pycrylhydrazyl (DPPH), EC (50) values were determined for A.herba alba and A.judaica $(0.122$, and $0.56 \mathrm{mg} / \mathrm{ml}$ ) growing in Saudi Arabia and A.herba alba and A. judaica (1.7 and $0.67 \mathrm{mg} / \mathrm{ml}$ ) growing in Egypt. Total alkaloid content was analysed and some alkaloid compounds was identified by GC-MS, viz. dasycarpidan-1-methanol, acetate, pseudosolasodine diacetate and morphinan4,5epoxy3,6diol. Certain compounds were rich in Saudi plant but not detected in plants grown in Egypt, which reflect the role of environment adaptation of plant by accumulation of only certain compounds.
\end{abstract}

Keywords: Artemisia Judaica, Artemisia Herba Alba, Alkaloid Compounds, Antioxidant, Phenolic

\section{Introduction}

The morphology and physiology of plant are strong-

ly affected by drought and environmental condition, which cause a large reduction in agricultural production. The endemic plants are more adaptable to environmental conditions than agronomic commercial crops. ${ }^{1}$

Fulda et al., 2010, Report oxidative stress is a metabolic status, which increases reactive oxygen

\footnotetext{
${ }^{*}$ Author for correspondence
} 
species (ROS) production. Cell injury results in cell viability compromise through apoptosis or necrosis. $^{2}$

Desert plants subject to water deficiency conditions produced high concentration concentrations of natural compound and secondary metabolite than same species grow under high water supply. Water deficiency induces drought stress-related metabolic responses, generating a large oxidative stress. As a consequence, metabolic processes are shifted towards biosynthetic activities that consume reduction equivalents. Accordingly, the synthesis of some products, terpene, phenols and alkaloids, are enhanced. Huda et al., 2015 and Esmaeili et al., 2011, ${ }^{3,4}$ reported that secondary metabolites play key physiological roles in plant growth development, reproduction and disease resistance.

Simple phenylpropanoids (caffeic, ferulic, sinapic acids and P-coumaric ), with basic skeleton C6-C3 of phenylalanine, are produced from cinammate via a series of hydroxylation, dehydration and methylation reactions. The free acids rarely accumulate to high levels inside plant cells; instead, they are usually conjugated to sugars (salicylate-glucose conjugates), cell wall carbohydrates (ferulate, esters),.5,6 .

\subsection{Aim of Study}

Wild plant grow and survive in drastic conditions of water deficiency and high temperature, aridity try to adapt to these condition by accumulation some active compounds such as alkaloid, flavonoid and terpene, phonolic compound, in present study we discuss the accumulation of alkaloid and phenolic compound by which the plant Artemisia gudica and A. herba alba collected from two region, Tabuk, Saudi Arabia and North Sinai, Egypt adapt to oxidative stress.

\section{Material and Methods}

\subsection{Plant Material}

Fresh aerial parts of two plants from genus Artemisia, namely Artemisia herba alba and Artemisia judaica were collected from the arid zone at Arish-North Sinai, Egypt, and Tabouk region, Saudi Arabia, during the springseasons, 2016. Collected plants have been kindly verified and authenticated in the Desert Research Center, voucher specimens were deposited in the Herbraium of Desert Research Center.

\subsection{Phytochemical Screening}

The phytochemical analysis of methanol extracts were tests to identify different classes of bioactive chemical constituents (flavonoid-alkaloid- terpene and sterol) present in the plant using standard methods ${ }^{11,18}$.

\subsection{Phenolic Compound Extraction}

Phenolic compounds were extracted as described by ${ }^{1}$. Extraction was carried out in water bath. The solutions from all extractions were combined. After evaporating the organic solvent in a rotary evaporator at $45^{\circ} \mathrm{C}$, the crude extracts were stored at $-20^{\circ} \mathrm{C}$ until further analysis.

\subsection{Analysis of Phenolic Compounds}

Analysis was carried out by (GC-MS) after silylation by N-Methyl-N-Trimethylsilyl Trifluroacetamide (MSTFA), \%1 Trimethyl Iodosilane (TMIS). Numerous compounds were detected and identified $^{7}$. 


\subsection{Extraction and Identification of Alkaloid}

The fin powder aerial part of plant samples ( $\mathrm{g}$ ) were boiled in water bath with $20 \mathrm{ml}$ of $\mathrm{HCl}$ in $50 \%$ methanol. The mixture was cooled and filtered. A portion was reserved. Another portion of the filtrate was put in $200 \mathrm{ml}$ separating funnel then add drops of ammonia to alkaline the solution. Add equal volume of choloroform and shaken to allow the layer to separate. The chloroform layer was extracted with two quantities each of $5 \mathrm{ml}$ of dilute hydrochloric acid 9 .

\subsection{Analysis of Alkaloid Compound}

The constituents of the alkaloid extract and methanol extract analyzed by GC-MS as reported by $^{12}$. Compounds identified by comparison of their Retention Indices (RI), (C9 to C24 n-alkane mixture) and mass spectra with those reported in the literature $\mathrm{e}^{1,12}$.

\subsection{GC-MS Analysis}

The compounds were analyzed using a Thermo GC-Trace ultra system (Thermo Co. USA), they were separated on $30 \mathrm{~m}$ X0.25 mm X $0.25 \mu \mathrm{m}$ Elite5MS column (Thermo Scientific GC Column). The column temperature was increased from $40{ }^{\circ} \mathrm{C}$ to $220{ }^{\circ} \mathrm{C}$ at a rate of $4{ }^{\circ} \mathrm{C} / \mathrm{min}$; injector temperature, $250^{\circ} \mathrm{C}$; injection volume, $1 \mu \mathrm{l}$; helium carrier gas flow rate $20 \mathrm{ml} / \mathrm{min}$; transfer temperature, $280^{\circ} \mathrm{C}$. MS parameters were as follows: EI mode, with ionization voltage $70 \mathrm{ev}$, ion source temperature, $180^{\circ} \mathrm{C}$; scan range, $50-600 \mathrm{Da}$. The peaks were tentatively identified based on library search using NIST and Wiley Registry 8 Edition.

\subsection{Antioxidant Activity}

\subsubsection{DPPH Radical Scavenging Capacity}

In this study, $0.5 \mathrm{~mL}$ of each sample concentration was homogenized with the same volume of DPPH methanolic solution $(0.04 \mathrm{~g} / \mathrm{L})$. The mixture was shaken vigorously and allowed standing for $30 \mathrm{~min}$ in darkness at a temperature of $25^{\circ} \mathrm{C}$; the absorbance of the resulting solution was measured at 517 $\mathrm{nm}$ with a spectrophotometer ${ }^{13}$. The percentage inhibition was calculated as:

Ascorbic acid and quercetin were used as positive control, the concentration providing 50\% inhibition $\left(\mathrm{IC}_{50}\right)$ was calculated from the graph of inhibition percentage plotted.

\section{Results and Discussion}

Methanol extracts of the aerial part of plants, (A.herba alba and A. judaica) Figure 1, grown in the arid zones in the Northern regions of Saudi Arabia and North Sinai in Egypt were subjected to primary phytochemical analysis which shown the presence of high amount of phenolic compounds, and flavonoids, absence of tannins in A.herba alba, alkaloid and sterols have moderate concentration as investigated in Table 1.

\subsection{Phenolic Compound}

The investigation of methanolic extract of plant samples of A.herba alba and A. judica by GC-MS exhibited different types of phenolic compounds, ferulic acid, 4-hydroxy-cinamic acid-ester, p-tertButyl-catechol, n-Propyl-cinnamate, Butyl-cinnamate, and ethyl-cinnamate and 2,4,6-Trimethyl- mandelic acid. Most compound found in ester form, compounds was shown in, Table 2. 
Artemisia herba alba

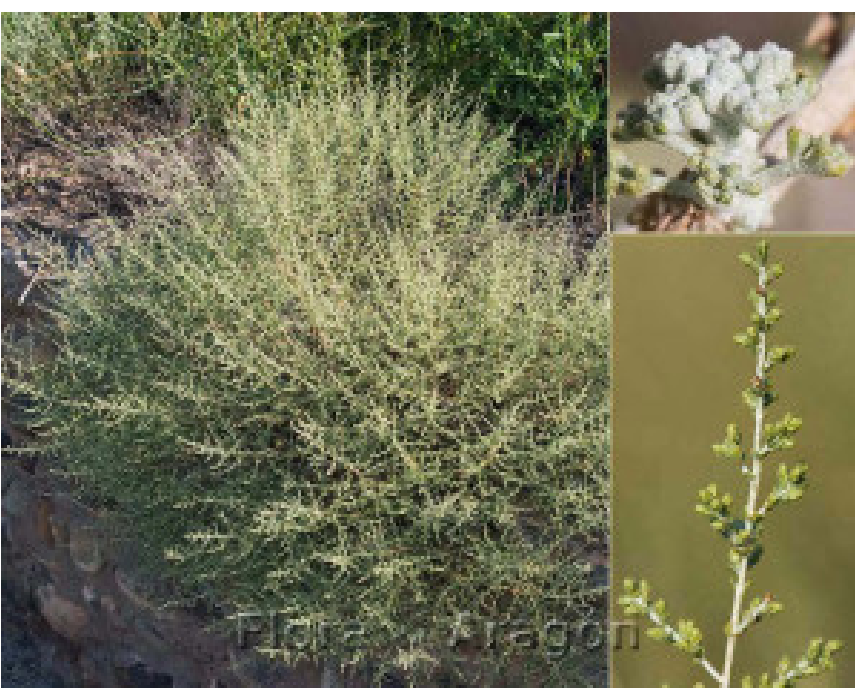

Artemisia judaica

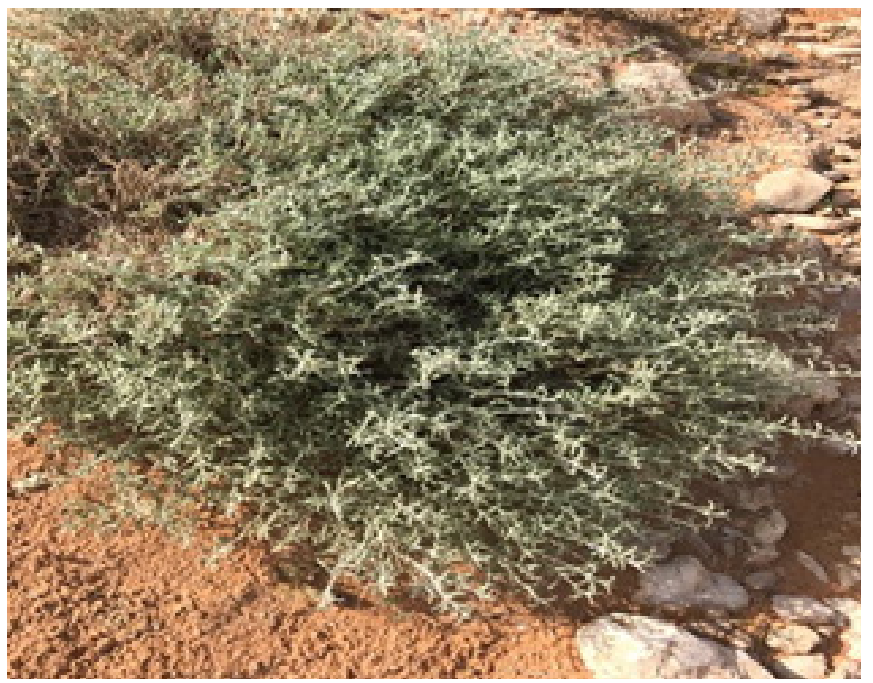

Fig. 1. The plants under study.

Table 1: Phytochemical screening of. A.herba alba and A. judica in two regions

\begin{tabular}{|c|c|c|c|c|}
\hline Measurement & $\begin{array}{c}\text { A.herba alba } \\
\text { Saudi Arabia }\end{array}$ & $\begin{array}{c}\text { A.herba alba } \\
\text { Egypt }\end{array}$ & $\begin{array}{c}\text { A.judiaca } \\
\text { Saudi Arabia }\end{array}$ & $\begin{array}{c}\text { A.judaica } \\
\text { Egypt }\end{array}$ \\
\hline Flavonoid & ++ & ++ & +++ & ++ \\
\hline Tannin & - & - & + & ++ \\
\hline Sterol & ++ & ++ & + & + \\
\hline Alkaloid & ++ & + & ++ & ++ \\
\hline Phenolic & +++ & ++ & +++ & ++ \\
\hline
\end{tabular}

$(+++)$ high concentration, $(++)$ moderate concentration), (+) low concentration ,(-) negative

The highest phenolics compound was shown in A. herba alba, collected from Saudi Arabia methyl cinnamate $(8.6 \%)$ and the lowest for 1,3-Bis ( cinnamoyloxymethyl-adamantane $(0.01 \%)$; also methyl-cinnamate are the highest (5.22\%) phenolics compound in A. judica grown in Saudi Arabia. The results showed high concentration of some phenolic compounds in Saudi plant compared with the plant grow in Egypt. As well, the phenolic compounds have an adequate chemical structure capable of scavenging free radicals which produced as a result of oxidative stress. 
Table 2: \% Amount Phenoilic compound identified by GC-MS in two plants from two regions

\begin{tabular}{|c|c|c|c|c|}
\hline \multirow{2}{*}{ Compounds } & \multicolumn{2}{|c|}{ Egypt } & \multicolumn{2}{|c|}{ Saudi Arabia } \\
\hline & A. herba alba & A. judica & A. herba alba & A. judica \\
\hline p-tert-Butyl- catechol & 0.20 & - & - & - \\
\hline $\begin{array}{l}\text { 2,4,6 Trimethyl mandelic } \\
\text { acid }\end{array}$ & 0.04 & - & - & - \\
\hline Methyl-cinnamate & 7.34 & 4.2 & 8.6 & 5.22 \\
\hline n-Propyl-cinnamate & 1.82 & 0.96 & - & 2.5 \\
\hline Ethyl cinnamate & 6.65 & 0.16 & - & 4.5 \\
\hline $\begin{array}{c}\text { Benzoic acid, } \\
\text { 4-hydroxy3methoxy, methyl } \\
\text { ester }\end{array}$ & 0.18 & 0.25 & - & - \\
\hline ferulic acid & 0.01 & - & - & 0.12 \\
\hline Ursodeoxycholic acid & - & - & 0.02 & 0.04 \\
\hline $\begin{array}{c}\text { 1,3 Bis } \\
\text { (cinnamoyloxymethyl) } \\
\text { adamantane }\end{array}$ & 0.13 & 0.16 & 0.01 & 0.02 \\
\hline Methyl ferulate & 0.02 & - & - & 0.10 \\
\hline
\end{tabular}

Many studied reported that, drought stress inhibits the total synthesis of phenolic compounds in leaves and roots ${ }^{19}$, in earlier research on seedlings of V. vinifera exposed to chilling stress. Found he total content of tannins and phenolic acids in stress sample was lower than in control and author in ${ }^{4}$ (Amarowicz et al., 2010) observed the same trend in leaves of $\mathrm{V}$. vinifera subjected to low temperature stress. On the other hand (Chung et al., 2010), observed quite the opposite effect, the chilling stress and water deficit caused an increase in the total content of phenolic compounds, our result was agree with . Chung et al., where the plant which subject to more arid condition in Saudi Arabia accumulate higher amount of phenolic compounds. Many studied confirm that the production of phenolic compounds in plant tissues rises under a biotic stress condition ${ }^{19,20}$.

In response to changing environmental conditions, plants evolved the capacity to biosynthesize different phenolic acids ${ }^{5}$. Here, four phenolic acid were identified in two plant, ferulic aid, cinnamic acid, benzoic and mandolic acid. The 
most abundant was cinnamic acid, while, phenolic acids were found as ester bounded form.

The presence of cinnamic acid in ester form as methyl, butyl or as ethyl related to habitat of plant grow was it is a mechanism of degrading of cinnamic acid according to adaption to high temperature, Similar results were shown by Weidner et al. (2011) on their study on Vitis californica, the ester-bound form of caffeic acid increased under stress conditions. Also author in ${ }^{4}$ (Amarowicz et al. 2010), study the effect of low temperature, on germination of Vitis vinivera, while the content of p-coumaric acid declined.

\subsection{Antioxidant Activity}

\subsubsection{DPPH Radical Scavenging Activity}

The antioxidant activity, DPPH free radicals scavenging activity reducing antioxidant assay of methanol extract of aerial parts of A.herba alba (0.122and $1.7 \mathrm{mg} / \mathrm{mL}$ ) in Egypt and Saudi Arabia respectively, where $A$. judaica has an important antioxidant activity with an $\mathrm{EC}_{50}$ of $(0.56 \pm 0.04$ and $0.67 \mathrm{mg} / \mathrm{mL}$ ) as Table 3 . These results is lower than that of ascorbic acid $\left(\mathrm{EC}_{50}: 0.095 \pm 0.002\right)$ and quercetin $\left(\mathrm{EC}_{50}: 0.019 \pm 0.003\right)$. The antioxidant activity of this extract is due to its chemical composition, which showed the presence of different phytochemical groups that have an antioxidant activity such as: alkaloids and phenolic compounds. Moreover, the chemical analysis using GC-MS allows identifying certain compounds which can be involved in the antioxidant mechanisms. Some studies were evaluated the efficacy ferulic acid and cinnamic acid as an antioxidant. Cinnamic acid derivatives $^{16}$ (Sharma, 2011), and Ferulic acid ${ }^{10,17}$.

The reduction of DPPH is accompanied by its passage from the violet color characteristic of DPPH solution to the yellow color measurable at $514-518 \mathrm{~nm}$. In this study, the reduce $50 \%$ of the $\mathrm{DPPH}$ radical $\left(\mathrm{IC}_{50}\right)$ was measured and the results showed that Artemisia herba alba grown in Saudi Arabia present higher antioxidant capacity with an $\mathrm{IC}_{50}$ of $0.122 \pm 0.001 \mathrm{mg} / \mathrm{mL}$, followed by Artemisia judica grown Saudi with an $\mathrm{IC}_{50}$ of $(0.56 \pm 0.04 \mathrm{mg} /$ $\mathrm{mL}$ ) However, the antioxidant capacity of ascorbic acid and quercetin were $0.091 \pm 0.001 \mathrm{~g} / \mathrm{L}$ and 0.026 $\pm 0.002 \mathrm{~g} / \mathrm{L}$ respectively (Table 3 ).

\subsection{Total Alkaloid}

The total alkaloid content of all the two plant varied from $0.24 \pm 0.2$ to $1.26 \pm 0.3 \mathrm{mg} / \mathrm{g}$ of dried plant material. The Artemisia herba alba collected from Saudi Arabia show higher amount of alkaloid content. As in Table 1,this agree with (Mohammad Reza Amirjani 2013) ${ }^{\mathbf{9}}$ who reported that Seedlings of Catharanthus roseus was subjected to waterregimes, totalalkaloid content significantly increased to maximum $178 \%$ compared to the control. Vincristine and vinblastine content of the seedlings grown water regimes increased to $175 \%$ and $171 \%$ compared to the control, respectively. Authors in ${ }^{9}$ (Mohammad Reza Amirjani 2013) reported that the level of tropane alkaloid accumulation was

Table 3: Antioxidant Activity of Artemisia herba alba and A.judica

\begin{tabular}{|l|c|c|c|c|c|c|}
\hline Measurement & $\begin{array}{c}\text { A.herba alba } \\
\text { Saudi Arabia }\end{array}$ & $\begin{array}{c}\text { A.herba alba } \\
\text { Egypt }\end{array}$ & $\begin{array}{c}\text { A. judica } \\
\text { Egypt }\end{array}$ & $\begin{array}{c}\text { A. judaica } \\
\text { Saudi Arabia }\end{array}$ & $\begin{array}{c}\text { Ascorbic } \\
\text { acid }\end{array}$ & Quercetin \\
\hline $\mathrm{EC}_{50}(\mathrm{mg} / \mathrm{mL})$ & 0.122 & 1.7 & 0.67 & $0.56 \pm 0.04$ & $\begin{array}{c}0.091 \\
\pm 0.002\end{array}$ & $\begin{array}{c}0.026 \\
\pm 0.002\end{array}$ \\
\hline
\end{tabular}


Table 4: Total alkaloid $\mathrm{mg} / \mathrm{g}$ in Artemisia in two regions

\begin{tabular}{|c|c|c|c|}
\hline \multicolumn{2}{|c|}{ Artemisia judaica } & \multicolumn{2}{c|}{ Artemisia herba alba } \\
\hline Egypt & Saudi Arabia & Egypt & Saudi Arabia \\
\hline 0.24 & 0.32 & 0.86 & 1.26 \\
\hline
\end{tabular}

related to plant growth when he studied the effect of salinity stress $\left(153.8 \mathrm{~mol} / \mathrm{m}^{3} \mathrm{NaCl}\right)$, salt treatment increase the total alkaloid content in leaves.

\subsection{Alkaloid Compound}

The GC-MS analysis of the Alkaloid fraction of Artemisia herba alba and A. judaica detected different types of alkaloid compounds, was shown in, Table 5. Pterin-6-carboxylic acid, Pseudosolasodine-diacetat, Dasycarpidan1methanol-acetate, Morphinan4,5epoxy3,6-diol, Aspidospermidin17ol and Dihydrovallesiachotamine in a different concentration of each compound according to plant and its region.

Alkaloid compound detected by GC-MS reflect the environmental change and environmental

Table 5: Analysis of Alkaloid compounds in plants in two regions

\begin{tabular}{|c|c|c|c|c|}
\hline \multirow[b]{2}{*}{ Compounds } & \multicolumn{2}{|c|}{ Egypt } & \multicolumn{2}{|c|}{ Saudi Arabia } \\
\hline & $\begin{array}{c}\text { A. herba } \\
\text { alba }\end{array}$ & A. judaica & A. herba alba & A. judaica \\
\hline $\begin{array}{l}\text { Pterin-6-carboxylic } \\
\text { acid }\end{array}$ & 0.02 & 0.04 & 0.25 & 0.06 \\
\hline $\begin{array}{c}\text { Pseudosolasodine } \\
\text { diacetate }\end{array}$ & 0.08 & 0.21 & 0.08 & 0.31 \\
\hline $\begin{array}{c}\text { Dasycarpidan1 } \\
\text { methanol, acetate }\end{array}$ & 0.03 & -- & 0.35 & 0.21 \\
\hline $\begin{array}{c}\text { Morphinan } \\
\text { 4,5epoxy3,6-diol }\end{array}$ & ---- & ---- & 0.13 & 0.02 \\
\hline Aspidospermidin17ol & 0.01 & 0.22 & 0.31 & 0.02 \\
\hline Desulphosinigrin & - & 0.01 & - & - \\
\hline $\begin{array}{l}\text { Dihydrovallesia } \\
\text { chotamine }\end{array}$ & - & 0.01 & - & - \\
\hline
\end{tabular}


Table 6: Structure of compounds identified from A. herba alba and A. judica in two regions

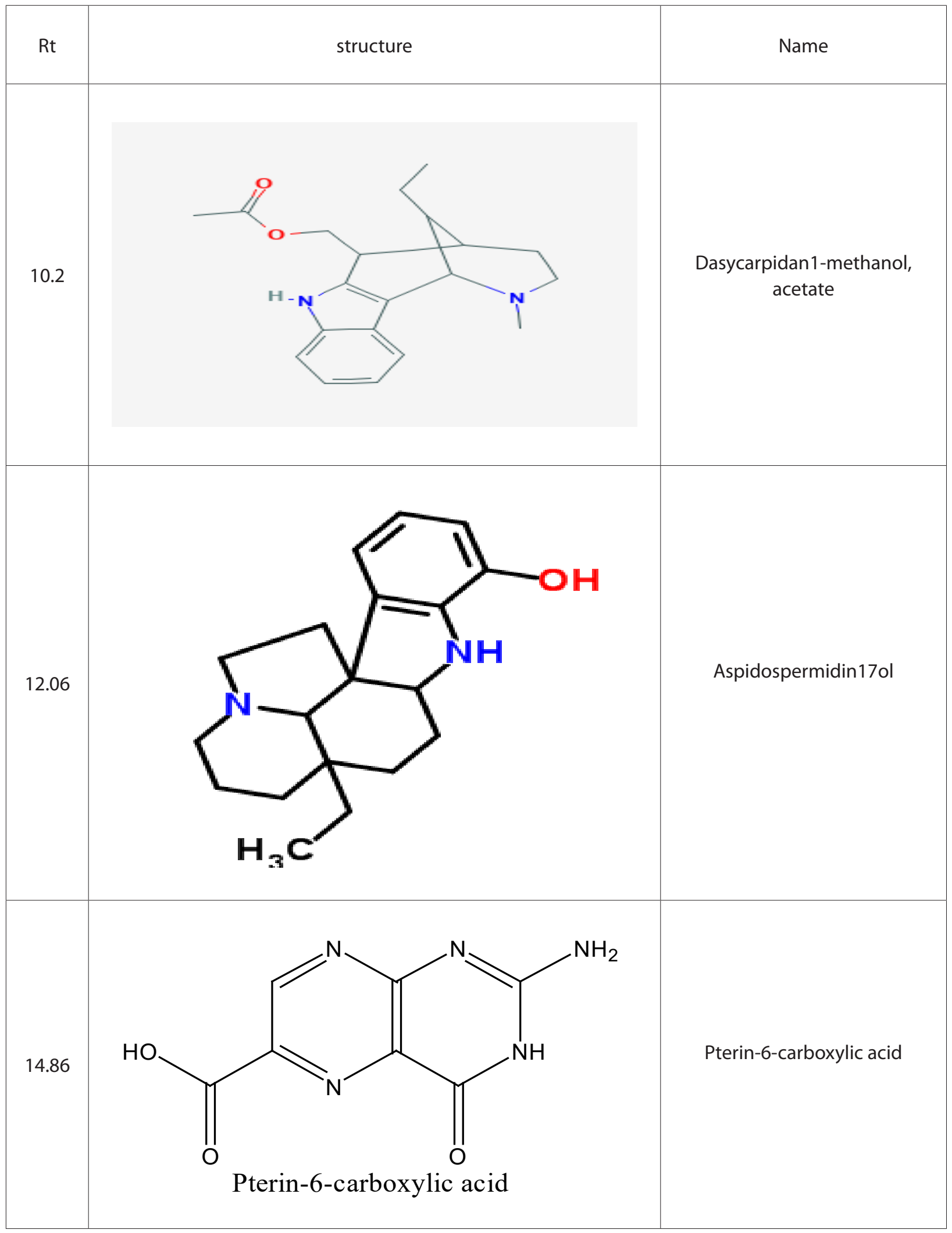




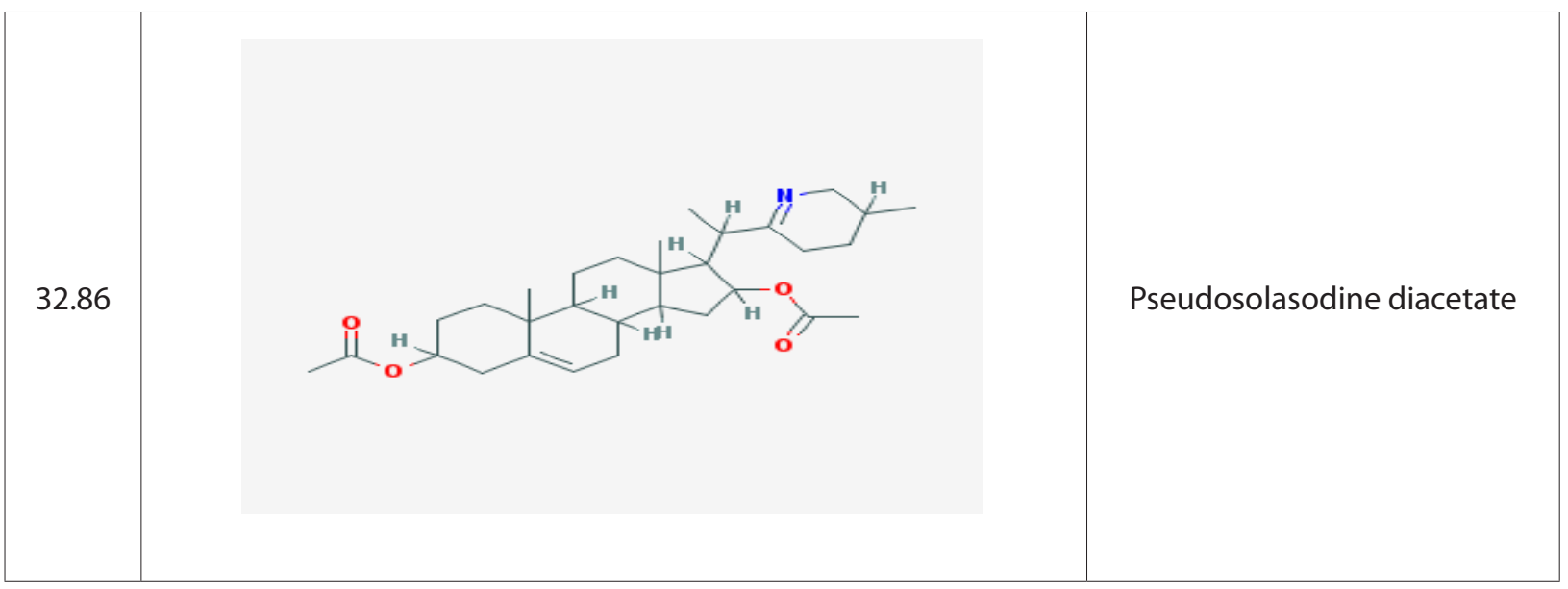

difference between two region from which the plant collected where some compounds are found in two plant in two region while other found in one habitat and not found in other, Morphinan-4,5epoxy-3,6-diol compound was significantly showed in concentration ( 0.13 and $0.02 \%$ ) for two plant $A$. herba alba and A. judaica grown in Saudi Arabia and not detected in the plant collected from Egypt. Where Dasycarpidan-1-methanol, acetate was not detect in A. judaica grown in Egypt, furthermore Desulphosinigrin and Dihydrovallesiachotamine only detected in A. judaica and not detected in other samples.

The concentration of some alkaloid compound in plant grow in Saudi Arabia was more than the plant grow in Egypt as (Dasycarpidan-1-methanol, acetate and Pterin-6-carboxylic acid) in two plant A. herba alba and A. judica this agree with ${ }^{2}$, Hansan et al., reported that, Gramine concentration in the leaf of Barley grown in Arimar was affected by temperature in the same way, gramine concentration remained low at suboptimal and optimal growth temperatures, increased sharply as temperature became moderately sup optimal, and began to fall when the heat stress was severe

\section{Conclusion}

The antioxidant activity of genus $A$. herba alba and A. judaica growing in Egypt and Saudi Arabia reflect the ability of plant to survive under drastic condition by the accumulation of some secondary metabolite, phenolic and alkaloid compounds, GC-MS-analysis of methanolic extract exposed numerous phenolic compound which have high antioxidant activity, cinammic acid, ferulic acid and nButyl- cinnamate, where alkaloid fraction analysis revealed the presence of Pseudosolasodine diacetate, Pterin-6-carboxylic acid and Aspidospermidin-17ol. These results proved the two plant species have high antioxidant activity espialy plant grow in Saudi Arabia which potent high antioxidant activity than plant grown in Egypt which reflexes the effect of environmental condition.

\section{References}

1. Andrade PB, Barbosa M, Matos RP, Lopes G, Vinholes J, Mouga T, Valentao P. Valuable compounds in macroalgae extracts. Food Chem. 2013; 138:181928. Crossref. PMid:23411314 
2. Hanson AD, Ditz KYM, Singletary GW, Timothy JL. Gramine accumulation in leaves of barley grown under high temperature stress' plant physiol. 1983; 71:896-904. 1/0896/09/\$00.50/0.

3. Amarowicz R, Weidner S. Biological activity of grapevine phenolic compounds. In: RoubelakisAngelakis KA, editor. Grapevine molecular physiology and biotechnology. 2nd ed. New York: Springer; 2009. p. 389-405. DOI: 10. 1007/978-90481-2305-6_14. Crossref.

4. Amarowicz R, Weidner S, Wojtowicz I, Karmac M, Kosinska A, Rybarczyk A. Influence of lowtemperature stress on changes in the composition of grapevine leaf phenolic compounds and their antioxidant properties. Funct. Plant Sci. Biot.2010; 4: 90-96. Crossref.

5. Caldwell MM, Bornman JF, Ballare CL, Flint SD, Kulandaivelu G, Chung IM, Kim JJ, Lim JD, Yu CY, Kim SH, Hahn SJ. Comparison of resveratrol, SOD activity, phenolic compounds compounds in Crocus sativus L. corms and its antioxidant activities study. Pharmacogn Mag cultures Planta. 2006; 188:594600 .

6. Dirk S, Maik K. Stress enhances the synthesis of secondary plant products: the impact of stressrelated over-reduction on the accumulation of natural products. Plant and Cell Physiology. 2013; 54(6):817-26. Crossref. PMid:23612932

7. Esmaeili N, Ebrahimzadeh H, Abdi K, Safarian S. Determination of some phenolic compounds in Crocus sativus L. corms and its antioxidant activities study. Pharmacogn Mag. 2011; 7:74-80. Crossref. PMid:21472084 PMCid:PMC3065162

8. Fulda S, Fulda AM, Gorman O, Hori A. Samali cellular stress responses: Cell survival and cell death. Int J Cell Biol. 2010; 23.

9. Altameme HJ, Hameed IH, Kareem MA. Analysis of alkaloid phytochemical compounds in the ethanolic extract of Datura stramonium and evaluation of antimicrobial activity. African Journal of Biotechnology. 2015; 14(19):1668-74.

10. Mathew S, Abraham TE. Ferulic acid: An antioxidant found naturally in plant cell walls and feruloyl esterases in $\neg$ volved in its release and their applications. Critical Reviews in Biotechnology. 2004; 24:59-83. Crossref. PMid:15493526

11. Mujeeb F, Bajpai P, Pathak N. Phytochemical evaluation, antimicrobial activity, and determination of bioactive components from leaves of Aegle marmelos. BioMed Research. 2014. Crossref. PMid:24900969 PMCid:PMC4037574

12. Pereira DM, Vinholes J, Guedes de Pinho P, Valentao P, Mouga T, Teixeira N, Andrade P. A gas chromatography-mass spectrometry multi-target method for the simultaneous analysis of three classes of metabolites in marine organisms. Talanta 2012; 100:391-400. Crossref. PMid:23141354

13. Abdallah, E.M., E.R. Elsharkawy, and A. Ed-dra, 2016. Biological activities of methanolic leaf extract of Ziziphus mauritiana. Biosci. Biotech. Res. Comm., 9(4): 605-614.

14. Schnltzler JP, Maudlung J, Rose A, Seitz HU. Biosynthesis of phydroxybenzoic acid in elicitortreated carrot cell cultures. Planta. 1992; 188:594600.

15. Shao HB, Chu LY, Jaleel CA, Zhao CX. Waterdeficit stress-induced anatomical changes in higher plants. C R Biologies. 2008; 331:215-25. Crossref. PMid:18280987

16. Sharma UK, Sharma N, Gupta AP, Kumar V, Sinha AK. RP-HPTLC densitometric determination and vali $\neg$ dation of vanillin and related phenolic compounds in ac-celerated solvent extract of Vanilla planifolia. Journal of Separation Science. 2007; 30:3174-80. Crossref. PMid:18027359

17. Srinivasan M, Sudheer AR, Menon VP. Ferulic acid: Therapeutic potential through its antioxidant property. Jour $\neg$ nal of Clinical Biochemistry and 
Nutrition. 2007; 40:92-100. Crossref. PMid:18188410 PMCid:PMC2127228

18. Yusuf AZ, Zakir A, Shemau Z, Abdullahi M, Halima SA. Phytochemical analysis of the methanol leaves extract of Paullinia pinnata lin. Journal of Pharmacognosy and Phytotherapy. 2014; 6(2):10-6. DOI: $10.5897 /$ JPP2013.0299.

19. Weidner S, Karolak M, Karamac M, Kosinska A, Amarowicz R. Phenolic compounds and properties of antioxidants in grapevine roots (Vitis vinifera) under drought stress followed by regeneration. Acta Soc Bot Pol. 2009; 78:97-103. Crossref.

20. Wrobel M, Karmac M, Amarowicz R, Fraczek E, Weidner S. Metabolism of phenolic compounds in Vitis riparia seeds during stratification and during germination under optimal and low temperature stress conditions. Acta Physiol Plant. 2005; 27(3A):313-20. Crossref.
21. Yalpani N, Ledn J, Lawton MA, Raskin L. Pathway of salicylic acid biosynthesis in healthy and virusinoculated tobacco. Plant Physiol. 1993; 103:315-21. Crossref.PMid:12231938 PMCid:PMC158986

22. Yalpani N, Ledn J, Lawton MA, Raskin L. Pathway of salicylic acid biosynthesis in healthy and virusinoculated tobacco. Plant Physiol. 1993; 103:315-21. Crossref. PMid:12231938 PMCid:PMC158986

23. Mohammad R. Amirjani. Effect of drought stress on the alkaloid content and growth parameters of Catharanthus roseus., ARPN Journal of Agricultural and Biological Science. 2013;. 8, 11.

24 Andrade, P.B., Barbosa, M., Matos, R.P., Lopes, G., Vinholes, J Mouga, T., Valenta o, P., Valuable compounds in macroalgae extracts. Food Chem. 2013; 138, 1819-1828. 